Click www.researchjournal.co.in/online/subdetail.html to purchase.

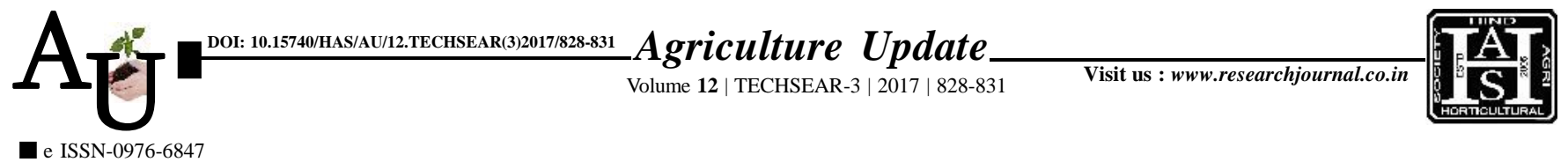

\title{
REsearch Aвticle: Rainfall characteristics and moisture availability index for crop planning in Parbhani district of Maharashtra
}

\author{
V.P. GANGANE，N.P. BUDDHEWAR AND R.K. SATHE
}

Article Chronicle:

Received :

13.07.2017;

Accepted :

28.07.2017

\section{KEY Words : \\ Rainfall \\ characteristics, Moisture availability \\ Index, Cropping \\ pattern, \\ Intercropping.}

Author for correspondence :

\section{R.K. SATHE}

Department of

Agronomy, College of

Agriculture, Vasantrao,

Naik Marathwada Krishi

Vidyapeeth, PARBHANI

(M.S.) INDIA

Email : rajivsathe510@

gmail.com

See end of the article for

authors' affiliations
SUMMARY : The present investigation entitled "Rainfall Characteristics and Moisture Availability Index for Crop Planning in Parbhani District of Maharashtra." Rainfall characterization of Parbhani district of Maharashtra is studied for above mentioned aspect so as to suggest the crops and cropping systems for each taluka. The historical daily data of rainfall at each taluka of Parbhani district were collected from department of Agriculture Meteorology M.K.V., Parbhani and Collectorate office, Parbhani. The available for last 29 years which were used for further analysis and the result to that affect are presented.The statistical analysis for variability of rainfall indicated that year to year variation ranged between 27-32.2 per cent on annual basis with the standard deviation value of 252.2, 261.7, 234.5, 268, 261.7, 256.3, 224.3, 257.2, 170.1 for Parbhani, Gangakhed, Pathari, Jintur, Palam, Purna, Sailu, Sonpeth and Manwattaluka respectively. The data indicated that the highest mean annual rainfall of $965.9 \mathrm{~mm}$ was recorded at Jinturtaluka. The lowest mean annual rainfall was recorded in $798.8 \mathrm{~mm}$ Sonpethtaluka.The mean seasonal highest rainfall was recorded in Purnataluka $850.0 \mathrm{~mm}$. While lowest mean seasonal rainfall in Manwattaluka $641.3 \mathrm{~mm}$. The data presented in the indicated that mean highest post monsoon rainfall ranged between 82.4 to $146.3 \mathrm{~mm}$ in different talukas. Winter seasonal rainfall data indicated that the mean highest winter seasonal rainfall was $9.4 \mathrm{~mm}$ in Parbhani and lowest rainfall was recorded as $2.0 \mathrm{~mm}$ in Manwattaluka. In Parbhanitaluka data indicated highest rainfall recorded in month of July $214.6 \mathrm{~mm}$. Standard deviation values highest in month of July $165.5 \mathrm{~mm}$ and co-efficient of variation highest in February Month 295.0 per cent. The highest rainfall in almost all taluka was recorded in the month of September in Jinturtaluka $261.5 \mathrm{~mm}$. While in the month of July in Parbhani, Gangakhed, Pathritaluka and in the month of August in Palam, Purna, Sailu, Sonpeth and Manwattaluka. The data on mean weekly total rainfall in each taluka indicated that major rains significant from in situ management point of view. Hence the was concentrated from MW 23 to MW 42. The statistics of the weekly total rainfall indicated that the least co-efficient of variation for this period in discussion was noticed during this period indicating the concentration consistency of rainfall in this period.The weekly probability analysis dry and wet spell for occurrence of rainfall was carried out. It is observed data indicated that probability of occurrence of $20.0 \mathrm{~mm}$ rainfall is greater than 50 per cent from meteorological week $24^{\text {th }}$ and persists upto meteorological week 34 . The highest potential evapotranspration was recorded in MW $21(55 \mathrm{~mm})$ and lowest potential evapotranspration MW $52(18.6 \mathrm{~mm})$ at Parbhanidistrict.The MAI values increased from $23^{\text {rd }}$ MW reached 1.0 in next week dropped in $24^{\text {th }}$ and $25^{\text {th }} \mathrm{MW}$ and again increased to 1.0 in $26^{\text {th }} \mathrm{MW}$ in all the three types of soils. The MAI values remained 1.0 throughout the Kharif cropping period indicating moisture surplus. In Parbhani district Crops are 